\title{
The Fighting Man as Tourist: The Politics of Tourist Culture in Hawaii during World War II
}

\section{DAVID FARBER and BETH BAILEY}

David Farber is a member of the history department in the University of New Mexico and Beth Bailey a member of the history department at Barnard College.

During World War II roughly a million soldiers, sailors, and war workers spent time in the territory of Hawaii. In order to mediate the potentially explosive tensions produced by this influx of homesick and battle weary men into an unfamiliar and highly diverse society, the U.S. military command and Hawaii's ruling elites tried to cast wartime visitors in a carefully constructed role - that of tourists. ${ }^{1}$ Tourists, as sociologist Dean MacCannell has pointed out, see difference as pleasurable, rather than threatening, and the unusual as affirming their own way of life rather than challenging it. ${ }^{2}$ The paradigm of the fighting-man-as-tourist enabled wartime visitors to consume the "otherness" of Hawaii without risking loss of primary identity and without needing to directly confront or reject the "other." At least this was what military and civilian authorities hoped would occur. As they and the soldiers themselves discovered, the role of tourist was a contested one. While elites might proffer a certain model of touristic behavior, it could be rejected or adapted to other purposes. During World War II, the paradigm of "tourism" in Hawaii was hotly contested and carried surprising political import.

1. For an overview of Hawaii during World War II, see Beth Bailey and David Farber, The First Strange Place: Race and Sex in World War II Hawaii (New York, 1992).

2. Dean MacCannell, The Tourist: A New Theory of the Leisure Class (Rev, ed., New York, 1989). 
By the time war clouds darkened the blue skies of the $\mathrm{Pa}$ cific, Hawaii existed as a tourist fantasy. In the first decades of the twentieth century, "Hawaii" had been purposefully constructed by businesses that lived on tourism, and then elaborated in thousands of public and private fantasies in the new consumer culture of America. Even before the United States officially claimed the Hawaiian islands, American business interests and the Hawaiian monarchy took steps to make Hawaii more accessible to travelers from the mainland. In the nineteenth century, the governments of King Lunalilo and King Kalakaua subsidized steamship lines, and King Kalakaua's government issued $\$ 116,000$ worth of bonds to finance the building and furnishing of the Royal Hawaiian Hotel. Following the overthrow of the monarchy and annexation, the newly solidified business-government alliance intensified efforts to promote tourism. In 1902 the Honolulu Chamber of Commerce and Merchants' Association sent O. C. Weedon, a Honolulu businessman, to tour the mainland with a set of tinted stereopticon slides. The following year the chamber of commerce created the Hawaii Promotion Committee, which was jointly funded by private interests and the territorial government (the legislature allocated $\$ 15,000$ for its first year of operation). This organization, which would change its name to the Hawaii Tourist Bureau in 1919, oversaw the business of advertising Hawaii to mainland America.

Hawaii's business elite also addressed the structural problems that inhibited tourism. The Matson Navigation Company built its first passenger liner, the Lurline, in 1908; successively more luxurious liners (the Wilhelmina, 1909; the Matsonia, 1913; the Maui, 1917) followed. By the early 1920s, Hawaii's economic powers had decided they could successfully compete for the elite tourists who normally travelled to the traditional tourist sites of Europe and the Mediterranean. Matson began constructing a new luxury liner, the Malolo, and a new grand hotel, a reincarnated Royal Hawaiian on the beach at Waikiki. ${ }^{3}$

The Hawaii crafted by the Tourist Bureau would be recog-

3. Edward Joesting, Tides of Commerce (Honolulu, 1983), 127-129; Thomas Kemper Hitch, Islands in Transition (Honolulu, 1992), 117-121. 
nizable today. The word "paradise" was predictably overworked, and the stock images-the silhouettes of Diamond Head, the dusky hula girls-all evolved into a coherent image of the safely exotic. "HAWAII: Joyous days in a setting where centuries ago the pagan made 'care' and 'must' taboo" offered a $1931 \mathrm{ad}$. Another from the same year promised "the soft thrill of tropic nights," a hula girl dancing on the beach, palms silhouetted against a full moon, Diamond Head in the background, all only "a week away." The islands were, a 1920s pamphlet claimed, "Lotus isles of love and laziness. The loveliest fleet of islands that lies anchored in any ocean. No fogs, no hurricanes, no poisonous plants. Tropical fruits you can enjoy without limit, water you can drink with safety, and plumbing that is American."4

The Hawaii Tourist Bureau was not alone in promoting Hawaii. Other, larger businesses offered a different sort of tourism-vicarious tourism-to the American public. They, more than any advertising scheme or tourist bureau, created the Hawaii of tourist fantasies. As Americans embraced more sensual and sexual forms in their public culture, the producers of popular culture looked outward to "exotic" and "primitive" cultures. In 1916, suddenly, the hula was everywhere in the theaters and cabarets of American cities. Chorus girls appeared in bare legs and grass skirts, dancing their versions of hula to the accompaniment of ukuleles. The originator of the mainland hula craze was a young woman named Doraldina who had no connection to the islands. The New York Times praised her hula for preserving its "sensuous gracefulness and its exotic originality... at the same time so that the sensitiveness of Western audiences will not be outraged by the native hula in all its primitiveness." 5

The hula, from the 1910 s through the 1930 s on the mainland, stood for exotic sensuality; Hawaii itself came increasingly to stand for romance. Throughout the 1920s and 1930s, Americans bought sheet music for "Hawaiian" songs, ranging from Al Jolson's "Along the Way to Waikiki" (1917) to the 1930s' "Do

4. For a unique and beautiful collection of mainland images of Hawaii, see DeSoto Brown, Hawaii Recalls: Selling Romance to America-Nostalgic Images of the Hawaiian Islands, 1910-1950 (Honolulu, 1982).

5. Ibid., 124-125; Lewis Erenberg, Steppin' Out (Westport, Conn., 1981), 224-225. 
the Hula" and Harry Owens's "Sweet Leilani." Cover art for the sheet often featured dark-skinned barebreasted "hula girls" with leis artfully arranged. Others promised romance, with elegantly attired tourists dancing under the stars. There was even a "Romancin' at the Royal" (Hawaiian Hotel) record label. Millions of Americans listened to the strains of romance direct from Waikiki on their radios on the popular program "Hawaii Calls."

But even more than radio, it was the movies that constructed "Hawaii." The Hawaiian setting was so common in movies that one New York Times film reviewer wrote sarcastically of "the well-known Hollywood suburb of Wacky-ki." The most unlikely people turned up in grass skirts. Clara Bow, in 1927, performed a "native dance" in the character of "Hula Calhoun." Eleanor Powell hula'd in Honolulu, and a whole troupe of dancers under the direction of LeRoy Prinz hula'd around "tribal campfires" in Bing Crosby's Waikiki Wedding.

Americans also saw movie stars who were "really" in Hawaii. There was a strong market for publicity stills of stars and other celebrities, and when America's favorites-Shirley Temple, George Burns and Gracie Allen, Spencer Tracy, Clark Gable, Mary Pickford and Douglas Fairbanks-vacationed in Paradise, the American public saw their pictures. ${ }^{6}$ In fact, by the 1920 s Hawaii had become a tourist "paradise" for an international elite. After the Prince of Wales and Lord Louis Mountbatten visited Honolulu twice in 1920, the islands attracted a growing stream of wealthy visitors. In the years between 1910 and 1921, the number of tourists grew from 5,000 to 8,000 , but by 1925 the number had increased to 15,000 , and four years later Hawaii was playing host to 22,000 visitors. ${ }^{7}$ The Great Depression of the 1930s almost halved that last figure, though wealthy tourists still made the long and expensive trip to Paradise.

The tourist Hawaii of the 1920s and 1930s was a world of luxury; the tourists almost without exception were people with wealth and time. It took five days to reach Hawaii from the West Coast by ocean liner. In 1936 Pan American Airlines began of-

6. Brown, Hawaii Recalls, 70, 128-129; Stan Cohen, The Pink Palace (Missoula, Mont., 1993), 88-91.

7. The statistics and information on elite tourism are taken from Hitch, Islands in Transition, 119-121. 
fering commercial flights from San Francisco to Honolulu. These flights took between eighteen and twenty hours and cost $\$ 278$ one way, a figure roughly equivalent to first-class passage on a ship. ${ }^{8}$ There were no "tourist-class" hotels in the islands. The hotels to which these visitors came were the elegant Moana, Halekulani, and, after 1927, the spectacular new Royal Hawaiian Hotel, built through the combined efforts of Castle \& Cooke (one of Hawaii's "Big Five" economic powers) and the Matson Navigation Company. ${ }^{9}$ The Royal Hawaiian (sometimes known as "the Pink Palace") was built in the fanciful pseudo-Moorish style popular in the $1920 \mathrm{~s}$, with a facade of pink stucco. It sat on a lushly landscaped fifteen acres on the beach at Waikiki. The firm of N.W. Ayer handled its advertising, and the Honolulu Star Bulletin predicted that it would transform Hawaii into "the Playground of the Pacific." 10

In the Royal Hawiian's first five years, 14,000 guests stayed in the 400-room "palace." Many came for an extended stay, equipped with steamer trunks and servants. Some even brought their cars. Guests during the 1920s and 1930s included Rockefellers, Fords, Du Ponts, the Shah of Iran, Henry J. Kaiser-and, of course, a multitude of Hollywood stars. In the years before World War II, Hawaii's tourists came from the economic and social elite. Just as many mainland Americans knew "Hawaii" as a sometimes odd combination of the exotic and the romantic, residents of Hawaii knew "tourists" were white people with enough money to stay in places like the Royal Hawiian.

There were, however, other visitors to the islands. They included workers from ships that docked in Hawaii and members of the "pineapple army," as the U.S. Army in Hawaii was often called. These working-class men were stationed for a time in the islands and, though never confused with "tourists," prompted the emergence of a range of institutions to serve them and accounted for a fair share of Hawaii's income in the prewar years. Among the earliest were whalers who were arriving in 600 ships

8. Ibid., 121; Brown, Hawaii Recalls, 90.

9. The building of the Royal Hawaiian Hotel was plagued by problems. The architect (from the well-known New York firm of Warren and Wetmore) did not visit the site in advance; the hotel began to sink before it was completed; and the costs for construction, budgeted at $\$ 2$ million, exceeded $\$ 4$ million before the building was completed. Hitch, Islands in Transition, 121.

10. Ibid., 120-121; Cohen, Pink Palace, 42. 
a year by 1840 . Records indicate that 18,700 "visitors" (most from whaling vessels) landed in Hawaii in 1846. Though whaling declined, sailors of various sorts remained an important presence in the streets of Honolulu. ${ }^{11}$

Following the annexation of Hawaii in 1898, the U.S. government began to create a military presence in the islands, dredging Pearl Harbor, establishing forts, even buying Diamond Head for emplotment of guns. In 1920 there were approximately 7,000 servicemen stationed in the islands. As Japan more actively asserted its power in the Pacific, the presence of U.S. forces increased. After the Axis powers signed the Tripartite Pact in September 1940, there were 48,000 troops stationed in the islands. ${ }^{12}$

These military men did not fit easily into the social structure of Hawaii. There was no substantial white working class in the islands and there was a large divide between the white (haole) population, most of whom were economically well-off, and the rest of Hawaii's residents. Those residents included native Hawaiians and, outnumbering them, other peoples from Asia and the Pacific, many of whose parents and grandparents had come to the islands as plantation laborers. Hawaii had a remarkably diverse population, and the level of racial tolerance (if not equality) was higher in the islands than on the mainland. But in the existing race-class hierarchy, there was no place for these working-class whites, many of whom were rough and poorly educated.

Those men who came to Hawaii through the shipping trades or as enlisted men in the military were largely invisible to the sort of people who ran and sponsored the Hawaii Tourist Bureau. On shore leave or pass they usually went to the bars and brothels of the Hotel Street district in Chinatown. These visitors and temporary residents spent money, but to the residents of Hawaii, they were not "tourists"-that is, people who had travelled to Hawaii for the purpose of tourism. The word "tourist" in prewar Hawaii was definitely class-linked.

11. Noel J. Kent, Hawaii: Islands under the Influence (New York and London, 1983), 22-23. The whaling industry was an important part of Hawaii's emerging capitalist economy, and its sailors spent close to $\$ 100,000$ annually in the mid-nineteenth century.

12. Hitch, Islands in Transition, 122-125. 
The Japanese attack on December 7, 1941, launched the entire United States into war, but Hawaii felt the presence of war more immediately than any of the forty-eight states. The territory was under martial law until late 1944. Every night there was a total blackout; no light could show anywhere on the islands. The newspapers were censored, and so was civilian correspondence. There were curfews and shortages, and at first everyone carried gas masks, even to weddings. For the first half of 1942, as fighting in the Pacific went badly for the Allies, the Hawaiian islands were, in fact, in danger. Tourists caught in the islands at the onset of hostilities evacuated as soon as possible. Along with them went about 20,000 military dependents and 10,000 other residents of the islands, mostly women and children who belonged to the haole elite. The first evacuation ship reached San Francisco on Christmas Day. It had been a grim and frightening passage on a ship also carrying badly wounded survivors of the Pearl Harbor attack. ${ }^{13}$

Tourism was over for the duration, but with the outbreak of war came a flood of people: servicemen and war workers. Hawaii would serve as staging ground for much of the Pacific war. There men trained for the island assaults and recovered from battle. Huge numbers of workers were needed to maintain and repair the ships and planes as well as to handle the logistics of troop movement and supply. Hundreds of thousands of servicemen and war workers spent some significant length of time in Hawaii, and at least a million passed through the islands where the civilian population in 1940 had been only 258,000 .

The wartime pressures on island resources were staggering, and the cultural dimensions of this influx of men were immensly complicated. Hawaii was "America," but unlike any America the men from the mainland-for all the differences among them - had ever known. Hawaii was a multiracial society (a full third of its population were Americans of Japanese ancestry), with local customs and ways of life intensely foreign to mainland Americans. Under pressure of war, under pressure of overcrowding and shortages (including the much discussed "woman shortage"), these differences had the potential to become explosive.

13. Gwenfred Allen, Hawaii's War Years (Honolulu, 1950). 
The military and the haole business elite adopted models of tourism in an attempt to mediate and manage tensions. The concepts of tourism and island paradise that they employed, however, were complicated metaphors that ultimately aroused the resentment of the men they were meant to manage. Military models of tourism were evident not only in the relatively traditional morale efforts of the USO, but also in the structure of specific programs and in the language and controlling metaphors of official publications. For the military, models of tourism seemed to offer a way to manage the charged issue of racial and ethnic difference in this (American) place. The soldier-as-tourist model was also supposed to mystify the fact of war, thereby combating the debilitating effects of boredom and alienation among men who waited, in Hawaii, to move into the battles raging in the Pacific.

Most American soldiers who spent time in Hawaii during World War II received a Pocket Guide to Hawaii, prepared by the Special Projects Branch, Morale Services Section, Central Pacific Base Command. Written in a plain-spoken, tough-guy idiom, the guide emphasized two seemingly contradictory messages. On the one hand, soldiers were admonished to understand that Hawaii was an exotic land that would offer its charms only to the open-minded and adventurous. The Guide begins: "This is about Hawaii, to introduce you to a new country. New countries are like new friends. You can't get to enjoy them until you've learned something about them-until you know the score." ${ }^{14}$ Here and throughout much of the text, the guide's authors urged readers to learn the history and development of Hawaii and to talk with Hawaii's residents about the islands' special cultural richness. Calling the U.S. territory of Hawaii "a new country" emphasized its distance and difference from mainland America, but by comparing it to "a new friend," the guide made clear it was not a hostile or frightening place.

In a somewhat contradictory manner, just a few pages later, the Guide emphasized to its soldier-readers that Hawaii was, in fact, a part of the United States. Hawaii's residents-all of

14. Army Information Branch, Information and Education Division, Morale Services Section, Central Pacific Base Command, A Pocket Guide to Hawaii (Washington, D.C., [1942?]), Hawaiian Collection, Hamilton Library, University of Hawaii at Manoa. 
them, the guide stressed-are Americans: "There's one primary point to remember. No matter what the color of their skin, no matter how they appear, the civilians you see in the Hawaiian islands are Americans. They're just as proud of the stars and stripes as you are. Never forget that." 15 This warning was particularly underlined in regard to the " 157,990 people of Japanese descent" who lived in Hawaii: "Now get this straight. Most of these went to American schools. They learned to pledge their allegiance to the same flag you salute. They like American soft drinks. And one of their favorite radio comics is Bob Hope. They're Americans.... Don't sell them short."16

Overall, the text of the army's "pocket guide" presented a democratic, tolerant, and open-minded message to the troops stationed in Hawaii. Ironically, the illustrations accompanying the text carried a very different message. The guide's cover featured a drawing of a cute, naked, dwarfish, dark-skinned man shown from the rear, with his head turned. This little "Hawaiian" appears throughout the text. In a section on the history of Hawaii, the little naked man is pictured looking up to a gigantic, smiling, well-dressed white man carrying a briefcase ${ }^{17}$ Considering that the average Hawaiian man was taller and more powerfully built than the average white man, this representation served rather dramatically to undercut, or at least to shape, the message of tolerance and open-mindedness the text seemed to deliver to serviceman. The Hawaiian people, the army seemed to be suggesting, while interesting, are also primitive, and no threat to white America. The army's double-edged message nicely served what Dean MacCannell calls the tourist's "transcendent consciousness" which "is intimately linked to its [the touristic middle class's] capacity to subordinate other people to its values, industry and future designs." ${ }^{18}$

The officers charged with overseeing servicemen's time in Hawaii did much more than hand out official guidebooks that illustrated aspects of an official tourist code. They also set up a large-scale recreation program that sought to make the best of prewar tourist Hawaii available to America's fighting men. The

15. Ibid., 7.

16. Ibid., 7-8.

17. Ibid., 15.

18. MacCannell, Tourist, 13; see also pp. 1-16. 
USO and the Army Special Services, under direct control of Hawaii's military governor, took the lead in providing both GIs and war workers with genuine Hawaiian experiences. In 1944, for example, they offered "community days," sponsored by local ethnic organizations. The USO claimed that "the average GI learned more in a few hours about the lore and color of these islands than he ever could should he return to a peacetime Paradise.... [T] he community people who staged these days for him brought to them the old and the genuine and the cherished." On "Chinese Day," for example, thousands of GIs took pictures of a dancing Chinese dragon "brought out of retirement" for their enjoyment and edification. Hula dancers, too, became a common entertainment at every army encampment and navy base on the islands. And, as the USO reported in its official yearbook, "the men took to the native dance with gusto." In 1944, the USO alone served 2,621,051 men (many men must have gone to several USO functions). ${ }^{19}$ The USO and other official morale-builders did everything they could to keep men's minds off the war and to assuage homesickness. Hawaii was offered up as a tourist experience, as an incredible opportunity for enjoyable encounters with authentic and exotic "natives" once only available to the rich and the famous.

Besides providing a host of Hawaiian programs and entertainments, the U.S. Navy literally took over Hawaii's most luxurious hotel, the Royal Hawaiian, for the exclusive use of naval personnel-mainly submariners-on R\&R. At $\$ 17,500$ a month, the navy leased the Royal Hawaiian for over three-anda-half years. Sailors stayed for an average of ten days (enlisted men paid twenty-five cents a night) and were free to use all of the hotel's services. To accommodate the different recreational needs of the sailors, the navy turned the Royal Hawaiian's tennis courts into basketball courts while the famous hotel gardens were made over into a baseball diamond. Barbed wire lined the beachfront, the bar was turned into a soda fountain for the duration, and Japanese-American staff were laid off for "security reasons," but otherwise the Royal Hawaiian was still the Royal

19. USO Report, 1944, 58.02, USO no. 2, p. 8, Hawaii and Pacific Collection, Hamilton Library, University of Hawaii at Manoa. 
Hawaiian. ${ }^{20}$ However, the men did not act like the Royal Hawaiian's previous guests. Some of them carved their initials into doorframes. Cigarette burns scarred expensive furnishings. The sailors hung their clothes to dry on window frames and elegant lanais. And the hotel's management, wary of its new clientele, hid its entire, world-class collection of alcoholic beverages in the wine cellar, which had been sealed off so as to look like a part of the building's foundation. ${ }^{21}$ The management was well aware that the guests were not the tourists of yore.

The men knew it, too. Despite the military's best efforts to use Hawaii's tourist aura and facilities to manage the complex emotions of soldiers and sailors in a war zone, America's fighting men wrestled with their contradictory feelings about being, as one of them, Edward Grier, later wrote, "Stationed in Paradise."22 Most of the men did enjoy the touristic aspects of their Hawaii experience. Grier, for example, noted that, "like all other tourists, the newly arrived soldier was impressed with the beauty of the islands. The approach to Honolulu was incredibly beautiful, even from a transport... That first impression can never be wholly eradicated."23 Another GI, Frank Brannigan, was fascinated with the Hawaiian people, "an extremely beautiful race, big, strong, massive people."24 Men learned from local musicians to play the slack key guitar, relished being invited to luaus, and crowded the beaches whenever they could. ${ }^{25}$ As the army guidebook suggested, many of the men did seek out the "aloha spirit" and the well-advertised charms of exotic Hawaii while they waited for their combat assignments, or for the war to end, or for their futures to be made clear.

The "war nerves" with which most men lived while "stationed in paradise" shadowed the touristic moments that most

20. For a nice summary of the Royal Hawaiian Hotel during World War II, with pictures, see Cohen, Pink Palace. Special thanks to Susan Neel for bringing this source to our attention.

21. Ibid., 52-53.

22. Edward F. Grier, "Stationed in Paradise," The General Magazine and Historical Chronicle of the General Alumni Society of the University of Pennsylvania (N.p., 1946), offprint in Hawaii Pacific Collection, Hamilton Library, University of Hawaii at Manoa.

23. Ibid., 95.

24. Frank Brannigan, interviewed by Beth Bailey, Lawrence, Kan., July 1989.

25. Bailey and Farber, First Strange Place, esp. chaps. 1, 2, and 5. 
of them enjoyed while in Hawaii. At the USO's Club Mahalo, for example, the men relished dancing-if ever so fleetinglywith Hawaii's exotic women: "Hawaiians, Japanese, Chinese, Filipinos, Portuguese, Puerto Ricans, Spaniards, Javanese, Malayans, French, Danish, Germans, Jewish, and Hungarians... [and] the Chinese-Hawaiians and half-whites," as the club's director described them. But the club was also the scene of hundreds of brawls and drunken abuse and simple breakdowns in the codes of touristic behavior which were supposed to make the exotic flavor of the dances fun and different. As the club's director, Mabel Thomas, wrote in her diary on June 4, 1943: "The nastiest, filthiest crowd of men Mahalo has ever had"; on August 30, 1944: They "Climbed outside building very very abusive to girls and guards-all looking for fights. This was a hellish night thanks to the Navy. Not drunk but all so nasty to some of the girls"; and January 8, 1945: "Terrible battle.... Marines and Navy. One Marine killed; another not expected to recover, general free for all." 26

Metaphors of tourism were clearly not sufficient to overcome the fighting men's war nerves or their ideas about how they meant to use their off-duty hours. Especially for men just back from the horrors of combat, Hawaii's exotic differences could be grating, even enraging, and the military command knew it. After the Marines' Second Division defeated the Japanese on Tarawa, the troops were not allowed to take leave on Oahu for fear of how they would react to the Japanese-American population. Instead the men were sent directly to the big island of Hawaii to build an isolated base high in the saddle of the dormant volcanoes Mauna Kea and Mauna Loa. The navy was apparently correct in its assessment of the situation. Some of these Marines, while on errands to the tiny plantation towns near their base, became so enraged at the sight of local "Japanese" faces that they beat up several people. ${ }^{27}$ The USO and the

26. "Maluhia Army Recreation Center, Dairies of Mrs. Mabel Thomas, Hostess, April 27, 1943, to August 1, 1945," microfilm \$10010, reel 36.15, Hawaii War Records Depository, Hamilton Library, University of Hawaii at Manoa.

27. This story is mainly drawn from letters written by local people on the Big Island and noted in military censorship reports. "General Information Summary," box V9375, file LL-4, 1/1-15/44, p. 7; box V3975, file LL-4, 1/15-31/44, p. 10, Commandant's General Correspondence, Pacific Sierra Region, Record Group 181-PHNY, National Archives. 
army guidebooks could only go so far, for many fighting men, in mystifying the pressing reality of war.

The realities of war also pressed very hard on the men's often conventionalized expectations of what their experience in Hawaii, "the Paradise of the Pacific," would be like. One perceptive soldier wrote: "Before the war Waikiki was known to ten mainlanders for every one who knew anything about Pearl Harbor. The efficient Hawaii Tourist Bureau and the visible legends of Hollywood had produced the expectation of a vacation paradise... Naturally every service man in Honolulu at once heads for Waikiki." Sadly, he concluded, "it is today a pretty shabby neighborhood." ${ }^{28}$ And he was correct. Barbed wire ran along the beaches, nightlife was closed down for most of the war, glamour of any kind was in short supply due to wartime rationing, manpower shortages, and severe overcrowding of all public facilities. ${ }^{29}$ Men griped regularly in letters to the Honolulu newspapers, to each other, and in letters home about how disappointed they were with Hawaii as a tourist paradise. As five soldiers from New York declared, "We had some very mistaken ideas of this so-called Paradise of the Pacific. But after a year and a half on this rock we can only say that in all our wanderings this is about the worst spot we've ever been in."30

A great many soldiers and sailors responded to their frustrations by embracing the other Hawaii that had long existed to service the islands' nontourist visitors: the vice district known as Hotel Street. Here, for most of the war, regulated brothels, bars serving ersatz liquor, tattoo parlors, and hundreds of tawdry concession stands serviced thousands of soldiers and sailors everyday, from morning until nighttime curfew. In a featured column in the weekly army newspaper that served the midPacific, the Midpacifican, "Hotel Street Harry" offered soldiers a very different guide to Hawaii. His was a jaded survey of bars that served watered drinks for too much money, of prostitutes who add "a little glamour to an otherwise drab joint," of soldiers looking for fun and just a little human warmth among all the clip joints. He called Hotel Street the "Street of Lonely Hearts,"

28. Grier, "Stationed in Paradise," 99.

29. Open any wartime issue of Hawaii's major magazine, Paradise of the $\mathrm{Pa}$ cific, for a running commentary on the islands' more glamorous side.

30. Honolulu Star-Bulletin, Jan. 5, 1943, p. 6. 
summing up the experiences of the men who flocked to Hotel Street this way: "I don't think there is a worse feeling in the world than to be lonesome in a crowd. The Street is filled with men whose hearts are aching." 31 Harry argued that for too many soldiers and sailors, Hawaii-in whatever form-failed America's fighting men.

Hawaii's elites, who had worked so hard to make Hawaii a sophisticated tourist attraction and who looked forward both to statehood and to a postwar tourist revival, did not ignore these complaints. Throughout the war, in a variety of ways, they attempted to manage the discontent of men, so different from prewar tourists, who had come to their shores involuntarily. The actions of the territory's business leaders were motivated not only by patriotism and concern for "our boys," but also by concern for the islands' postwar welfare. Those residents who felt themselves responsible for Hawaii's wartime stability and future economic well-being had to address two major problems. The first was to defuse the tensions between Hawaii's citizens and the servicemen and war workers. The second was to insure that the experiences of servicemen and others in wartime Hawaii did not destroy the carefully marketed version of tourist paradise that had come to represent a very significant portion of the islands' economy.

All of Hawaii's people had to wrestle with this influx of "visitors." For most, that experience was unpleasant and complicated by the fact of war. Honolulu, especially, was enormously crowded, and it was difficult for residents not to conflate the hardships of war with the influx of frequently discontented men. These men crowded the buses, the restaurants, the beaches. And they caused an explosion in the sorts of services and amusements traditionally aimed at the nontourist class of visitors. It was hard to ignore the brothels when lines stretched around the block at 10:30 in the morning. It was hard to overlook the tawdry concessions and scams that had sprung up, just as it was hard to avoid the clusters of men, discontented and at loose ends, often inebriated, roaming the streets in search of paradise-or at least of something to do.

Both business and military leaders attempted to manage

31. "Hotel Street Harry," Midpacifican, Aug. 15, 1943, p. 10. 
the public aspects of the problem. The office of the military governor oversaw recreation facilities, trying to clamp down on the tawdry concessions that competed with the USO programs for the serviceman's dollar. Bars that did not follow regulations were put off-limits, and the MPs policed the vice district. One group of reform-minded leaders began a campaign to close down the brothels that were regulated jointly, if unofficially, by the civilian police and the military. Nonetheless, the tensions remained. Servicemen, even when drunk and disorderly, were granted some leeway by island residents, as most were all too aware of what the men would encounter-or had already encountered-in the Pacific war. The war workers, however, despite the fact that most were far from home and family and worked very long hours, were generally treated with less empathy than soldiers and sailors.

Thus, in Hawaii's attempts to handle tensions, the approximately 100,000 war workers who had driven Honolulu's civilian population up forty-seven percent in two years were immensely important. The 1944 report of the Hawaii USO, an organization which was very much connected to the haole elite, articulated this concern in a significant reworking of the tourist metaphor. The section titled "War Workers" began: "Every time one of the liberty ships eases into Pearl Harbor, it brings the anonymous authors of the greatest story of production ever written by a single nation - the war workers. They line the rails, thousands of them, and if the crossing has been rough, their faces are pale, for they are not the travellers nor sophisticates of America, just the backbone." 32 Paradise of the Pacific, the magazine that served as the semiofficial organ of the haole elite, made a similar, more public pitch. In an article titled 'You Can't Call 'Em Tourists," the author made clear that it was hard work that earned war workers the opportunity for bus tours of the island on their one-day-off-in-eight. "They look like tourists," he agreed, but admonished: "if you see them going around the island-remember, they are hard working men and women who are spending long hours every day so that our ships can take a decisive crack at the Axis. You can't call 'em tourists." 33

32. USO Report, 1944, file 58.02, USO no. 2, p. 9.

33. "You Can't Call 'Em Tourists," Paradise of the Pacific (June 1943), 17. 
They were not tourists. On that everyone agreed. But everyone was also aware that the servicemen and war workers could lay claim to tourist privilege in one significant way: they spent money. The Pocket Guide to Hawaii made that point-in language that suggested a claim on the islands' people-for its military audience. Before the war, it explained, tourism accounted for about $\$ 10$ million a year in Hawaii's economy, third in significance after the crops of pineapples and sugar. In its tough-guy idiom, the Guide continued: "There's a lot of talk floating around about the trade having been killed off by the war. But that's strictly a false rumor. Matter of fact, there are more visitors here than ever before. Granted, most of them are wearing white or khaki uniforms, but they pack a lot of purchasing power."34

Hawaii's newspapers and magazines made the same point. These visitors were not tourists, but if tourism were an economic category instead of a functional category or a class category, these newcomers were filling it nicely. Paradise of the Pacific pointed out in May 1944 that the amount of money spent on amusements in the islands had jumped eighty percent, or $\$ 5$ million dollars, since the beginning of the war. Money spent in retailing had increased more than seventy-five percent, and more than 8,000 new businesses-ranging from hotdog carts to major recreation centers-had been established during the first two years of war. ${ }^{35}$ Knowledge of the economic importance of servicemen-and, more importantly, war workers-probably did little to contain the spontaneous flare-ups between local residents and the military/war worker malihini (newcomers), especially since these confrontations were often predicated on both racism and cultural difference. But just as the military authorities had used the lens of the tourist to try and cast these differences (of race/ethnicity, of culture) as exotic and interesting rather than threatening, these same authorities claimed the economic power of the tourist in order to position the soldiers, sailors, and defense workers in the tense world of wartime Hawaii.

34. A Pocket Guide to Hawaii, 26-27.

35. "Honolulu-Island Boomtown," Paradise of the Pacific (May 1944), 2; see also Alan Beekman, "Amusement ... a la Concessions," North Pacifican (June 1945), 6 . 
Hawaii's business elite accepted the legitimacy of those claims, but also understood them to have a significance that was more than economic. The men spent money as captives. The larger question was what would happen after the war. The elite who worried about these issues were not naive. They understood that Hawaii would not simply return to its prewar equilibrium once treaties were signed and the men demobilized. The war had disrupted old patterns and had drawn Hawaii closer to the mainland U.S. The economy, politics, and culture of the islands would change-and that change had to be managed.

One strategy was to shape the opinions of the men from the mainland who had spent time in Hawaii during the war. As Hawaii moved toward statehood, their opinions about the place would matter. It was important to the business elite that Hawaii not appear as primitive or unstable. And they were especially concerned with portraying the economic and social power of the Big Five industries as just and democratic. These Islands of Hawaii was a free booklet produced by the Hawaii Sugar Planters' Association "as a gesture of aloha from the industry's fifteen thousand stockholders to the endless stream of wartime men and women visitors." The section on the history of Hawaii centered on the growth of U S.-oriented business and agriculture, not on the complex political and social history of the Hawaiian nation. "And there," the section concludes, "you have the beginning of Hawaii's much-maligned merchant princesfounders of the little understood and often criticized 'Big Five.' They were the sort of men who have built American enterprise throughout the land-men who arrived here broke, many of them-deckhands weary of a whaler's long months at sea, small clerks from the eastern seaboard, eager for adventures in far-off lands." 36

Significantly, the final and key passage in this booklet returned to the contested and contingent figure of the tourist. Those who had felt the need for this booklet understood that while the various authorities on the islands had used the coded power of "the tourist" to serve their own multiple ends-to mystify the reality of battle; to manage racial and cultural difference by casting it as exotic tourist spectacle; to reckon with the

36. Hawaiian Sugar Planters' Association, These Islands of Hawaii (1943; Honolulu, Oct. 1945), 22. 
power bestowed by the economic importance of tourist spending - the wartime visitors themselves also had recourse to a model of tourism. Whether they were cast as tourists or nontourists, depending on the circumstances of the moment, the men had necessarily experienced part of their stay in Hawaii as touristic. And that was only partly because the islands' residents and the U.S. military took advantage of Hawaii's attractions to smooth the troops' stay or to offer them R\&R. It was also because, long before most of them had heard of Pearl Harbor, they knew the silhouette of Diamond Head and the romantic strains of Hawaiian music from the beach at Waikiki. Hawaii had been quite purposefully constructed as tourist paradise and it was against those images that so many of the men measured their experiences. Those among Hawaii's elite who understood the tension produced by that comparison knew they had to retrieve it. Some of their efforts to do so were in cooperation with the military as they sought to provide the best possible recreation facilities for the men. But they also spoke on their own to the men.

The Sugar Planters' Association booklet, These Islands of Hawaii, which went through four printings and was distributed to as many servicemen and war workers as possible, ended on a note of apology. "[W] hat we'd like to do and what we can do," it noted, "... are two different things in wartime... . Hawaii can be no tourist paradise so long as the war continues." But after the war, it promised, things would be different. Hawaii would not and could not go back to "the good old days." Instead, the islands would move on to "something better": "America's postwar job of policing the Pacific will keep the Islands swarming with servicemen and wealthy with the money they'll spend. Post-war freedom from building restrictions will give the green light to constructing the accommodations, amusements and attractions that were un-needed before the war brought you here in such numbers and impossible to build since you arrived." 37 In the minds of the business elite, clearly, the metamorphosis of the tourist had begun.

This last section of These Islands, however, ends with a some-

37. Ibid., 37-38. The booklet ends, "Now that you've finished reading this, send it on to someone at home" (p. 40). 
what overdetermined metaphor for the failure of the touristic experience. Wartime Hawaii, it readily admits, does not appear as Paradise. "It's sort of like having a date at Waikiki with some slick chick," the booklet ventures, "telling the boys to be there as witnesses, and then having her turn up in a Gay Nineties bathing suit instead of a sarong. You know the charm is really there but try and convince the boys." Despite all the conscious and skillful uses of the figure of the tourist throughout the war, this awkward and ill-digested metaphor perhaps best suggests the historically and socially contingent nature of tourism in the Hawaii of World War II.

Elites used a paradigm of tourist very similar to the one described by MacCannel in their attempt to manage the experience of men on the brink of war. To some extent they were successful, but they were also conscious that the contradiction of model and experience could not be reconciled so simply. They realized that those contradictions and tensions might have real economic and social implications in the postwar world. In the meantime, the experiences of the men themselves disrupted the paradigm of tourist. The "slick chick" in the "Gay Nineties" suit was a conceit of the elites, once again, but it captures the instability of a contested paradigm in its images of (sexual) anger and frustration, and in its acknowledgement that value is derived from the desire of others. In the postwar world, Hawaii's managers knew, the charms of the islands must be ever more explicitly revealed.

After World War II, tourism in Hawaii did change dramatically. Jet airplanes made the long trip faster and cheaper, and by the early 1960s, Pan Am alone offered 10,000 seats a week to Hawaii. The tourists who flocked to the islands were drawn by many of the same images of exotic, romantic Paradise, but the tourists were no longer drawn solely from the rich and privileged. By 1967, twenty-seven percent of Hawaii's tourists came on package tours, and fully half of Waikiki's many hotels were booked by the tour companies. ${ }^{38}$ Just as many in Hawaii had foreseen during the war, the islands had to cater to a very different sort of tourist, and offer a different sort of tourist experience. Nonetheless, the images of Paradise that had been so

38. Kent, Hawaii, 171-172. 
threatened by the experiences of men at the edge of war remained the core of the tourist construct, "Hawaii."

$* * *$

During World War II, the Hawaii Visitors Bureau shut down, but tourism as a cultural metaphor proved amazingly resilient. It is crucial to understand, however, that the figure of the tourist in Hawaii during World War II was highly contested. That both military and civilian elites used models of tourism in attempts to defuse wartime tensions demonstrates the perceived power and flexibility of the tourist metaphor. To some extent, however, the generalized success of public models of tourism complicated the elites' task. The men who came to Hawaii by reason of war brought with them the mass-mediated tourist fantasy of "Hawaii." The touristic paradigm that offered consumable experience, a safely exotic Other that served as self-affirmation, collided with the reality of wartime Hawaii. These men were not tourists, and wartime Hawaii was not Paradise. But tourism supplied the discourse and the model through which their experiences were mediated. Caught between conflicting claims of the tourist model, the men felt betrayed, prompting the islands' elite once more to modify the metaphor of tourist in an attempt to soften that betrayal and prepare for postwar Hawaiian tourism. 